\title{
RELATIONSHIP BETWEEN TRAITS: COGNITIVE ABILITIES, GENERAL SELF-EFFICACY AND NEUROTICISM TO CAREER SUCCESS MEDIATED BY SPECIFIC SELF-EFFICACY
}

\author{
Wiwik Priyatin ${ }^{1 *}$ \\ Department of Human Resources Management, Faculty of Management, University of \\ Jenderal Soedirman
}

\begin{abstract}
This research is an associative correlational type of research with aim to analyze the correlation between traits of cognitive ability, general self-efficacy and neuroticism with career success mediated by specific self-efficacy. The data sample were 31 lecturers which were chosen by using random sampling technique of 68 lecturers of Diploma of Nursing in Banyumas and Cilacap Areas as sample size. The data was analyzed by employing multiple regression analysis and Pearson product moment correlation. The results showed that cognitive ability and neuroticism has no positive relationship to career success mediated by specific self-efficacy. Meanwhile, general self-efficacy has positively strong relationship to career success with specific selfefficacy as the mediator.
\end{abstract}

\section{Introduction}

Career success poses as main study in Human Resource Management Study. It is something that is very much needed and becomes important for every individual because the achievement of it is a form of success in his/her work and reflects personal satisfaction (Steyrer et al., 2001). Success in a career is everyone's dream as well, because a career is something that someone wants to achieve in the future as a measure of his/her success. This study entitled "Relationship between Traits: Cognitive Ability, General Self-Efficacy and Neuroticism on Career Success mediated by Specific Self-Efficacy which aimed to explain the relationship between traits: cognitive ability, general self-efficacy and neuroticism with career success among lecturers of Diploma of Nursing in Banyumas and Cilacap Areas. The population target in this study was lecturers of Diploma of Nursing in Banyumas and Cilacap Areas.

* Corresponding author: ${ }^{1}$ wiwikaura428@gmail.com 


\section{Methodology}

This research was an associative correlational type of research which aimed to analyze the correlation. The data sample of this study was 31 respondents from 68 lecturers by using random sampling as the sampling technique. Questionnaires were used to collect the data, Multiple Regression Analysis using SPSS was used for data analysis technique, and Pearson Product Moment Correlation was used to measure the strength of relationships between variables. The hypothesis framework is shown in Figure (1) and described as follows: $\mathrm{H} 1(+)$ Cognitive Ability is positively related to Specific Self-Efficacy (SSE), $\mathrm{H} 2(+)$ Specific Self-Efficacy has a positive relationship to Career Success, H3(+) General Self-Efficacy (GSE) is positively related to Specific Self-Efficacy, H4(-) Neuroticism has negative relationship to Specific Self-Efficacy, and H5(-) Neuroticism is negatively related to career success. Researcher used questionnaire from Shockley, at al., (2015) as a tool to measure career success and cognitive abilities, while for measured the general self-efficacy researcher used questionnaire from Schwarzer, R., \& Jerusalem, M. (1995), and to measure the specific self-efficacy for assignments difficulty level researcher used questionnaire from Bandura, (1998).

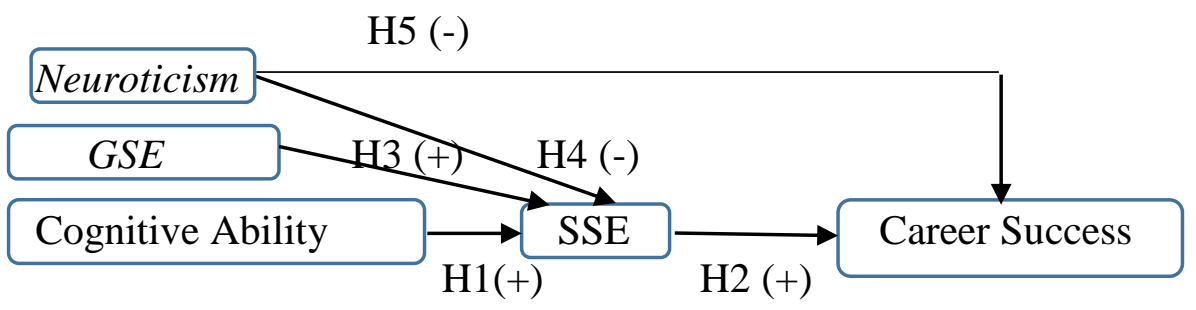

Figure. 1. A figure of a relationship between variables in this study

\section{Results}

Based on the analysis, this study found that cognitive ability had no positive relationship to career success mediated by specific self-efficacy, and Neuroticism had negative relationship to career success mediated by specific self-efficacy. Meanwhile, there was a positively strong relationship between general self-efficacy and career success mediated by specific self-efficacy. So, $\mathrm{H} 1$ and $\mathrm{H} 2$ were denied whereas H3, H4, and H5 were fulfilled. The results of the correlation test sig of cognitive abilities with specific selfefficacy was equal to $0.181>0.05$ so that there was no relationship, with Pearson Correlation value was 0.246 degrees means that the correlation is weak. However, the result of correlation test of sig neuroticism value with specific self-efficacy is $0.009<0.05$ means there is a relationship, with Pearson Correlation value was - 0.460 degrees means that it had moderate correlational relationship. Meanwhile, the results of the test of correlation sig value of general self-efficacy with specific self-efficacy is $0,000<0.05$ which means there was a relationship, with Pearson Correlation value was 0.796 degree which means it had strong correlation. By looking to the result, this study concluded that Neuroticism was negatively related to specific self-efficacy with a degree of moderate correlation. It had to be underlined that the respondents' demographic in this study were male and female whom mostly hold the master degree of nursing. 


\section{Conclusion}

A person with good cognitive abilities is able to increase confidence in his/her ability to mobilize his/her motivation to perform certain tasks (Wood \& Bandura, 1989). This is supported by the existence of human capital theory which states that an individual's progress and career success depend on the quantity and quality of human assets brought to the labor market (Becker, 1964). Supported by the research results including cognitive abilities have been proven to be important predictors of performance on various different tasks and it related to task performance through their positive relationship with specific self-efficacy (Stanley M. Gully, Robert, Giled Chen, et al ., 2000). In fact, this study found that there was no positive relationship between cognitive abilities and career success mediated by specific self-efficacy, so there was a gap between the theory and the results of this conducted study.

\section{Implication}

Further research is needed with a larger number of respondents. Quantitative research methods require a relatively larger sample size (over 30 respondents) in empirical observation (Jogiyanto, 2017) so that they can dig deeper into the relationship between cognitive abilities and career success mediated by specific self-efficacy.

\section{References:}

Adiyono, Ratno Purnomo,Wiwiek RA. (2017). Pengaruh Kepribadian Lima Faktor terhadap Kesuksesan Karir. Jurnal Bisnis dan Ekonomi (JBE). Vol.24, No.2, 162-176.

Abele E Andrea \& Spurk Daniel. (2009). How Do Objective \& Subjective Career Succees Interrelate Over Time. Laser, Labor and Socio-Economic Research Center University of Erlangen Nuremberg. Vol.85 No.35, 803-820.

Arnold Gesell, et. al., (2011). Maturation and Incomplete Man Test. Journal International Cognitive Ability.

Ballout.I Hassan. (2007). Carrer Success The Effects of Human Capital, Person-Environment Fit and Organizational Support. Journal of Managerial Psychology.Vol.22, No.8, 741-765.

Bridgstock, R .(2008). Follow your bliss or show me the money ? career orientation, career management competence and career success in Australian creative workers, Norwich Business Sshool ;University of East Anglia.

Coopersmith.S.(1967). Coopersmith Self- Esteem Inventory Form A. Self Esteem 
Institute.

Gully M.Stanley. (2000). Examination of Relationships Among TraitLike Individual Differences, State-Like Individual Differences, and Learning Performance. Journal of Applied Psychology.Vol.85. No.6, 835-847.

Guthrie P.James.(1998).Career Management Strategies: The Role Of Personality.Journal of Managerial Psychology.Vol. 13 No.5/6, 371386.

Jogiyanto. (2017). Filosofi dan Metodologi Penelitian. Cetakan Pertama. Yogyakarta: BPFE

Le Huy. (2011). Too Much of a Good Thing: Curvilinear Relationships Between Personality Traits and Job Performance. Journal of Applied Psychology.Vol 96. No.1, 113 - 133.

Luthans Fred. (2011). Oragizational Behavior An Evidence Approach.12th Edition

Nursalam. (2013). Metodologi Penelitian Ilmu Keperawatan. Penerbit Jakarta Salemba Medika. Edisi 3.

Pownall Ian. (2012). Effective Management Decision Making. Ian Pownall \& Ventus Publishing Aps.

Shockley, Heather, Laura, Timothy.(2016). Development of a New Scale to Measure Subjective Career Success: A Mixed-Methods Study.Journal of Organizational Behavior, J.Organiz Behavior. Vol .37,No., 128-153.

Song \& Day .(2016). Subjective Career Success: A Literature Review \& Prospect. Journal of Human Resource and Sustainability Studies. Vol 4, No., 238- 243.

Steyrer Johannes. (2000). Subjective \& Objective Career Success Empirical Findings From the Vienna Career Panel Project Based on The Nation of Career Habitus.

Srivastava \& O.P John. (1999). The Big - Five Trait Taxonomy: History, Measurement, and Theoritical Perspectives. Pevin \& O.P John (Eds), Handbook of Personality : Theory and research Vol.2 No., $102-$ 138. 
Suliyanto. (2018). Ekonometrika: Analisis Regresi variabel Dummy, Uji Asumsi Klasik, Validitas dan Reliabilitas, Path Analysis, Structural Equation Modeling (SEM). Tidak dipublikasikan.

Thomas, Kelly, Feldman. (2005). Predictor Of Objectif and Subjective Career Success: A Meta - Analysis. Personel Psychology. Vol 58, No. ,367- 408 .

Wang Mo \& Wanberg R Connie. (2017). 100 Years of Applied Psychology Researc on Individual Careers: From Career Management to Retirement. Journal of Applied Psychology.Vol.102, No.3, 546-563.

Scharzer, R,.\& Jerusalem, M. (1995). Generalized Self-efficacy Scale. In J. Weinman, S.Wright, \& M.Johnston, Measures in health psychology: A user's portofolio. Causal and conrtol beliefs.vol.,No.,35-37. 